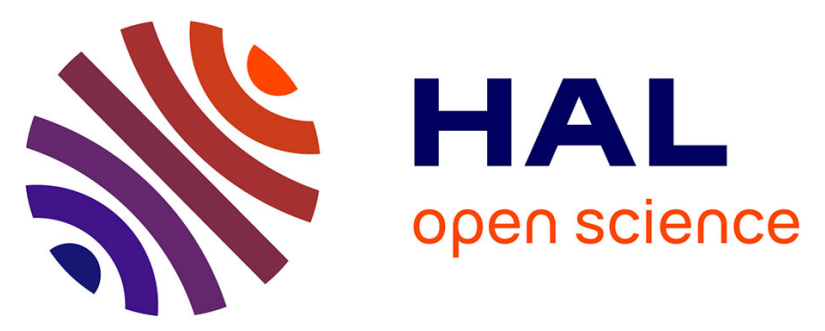

\title{
Comment on "The moisture from the air as water resource in arid region: Hopes, doubt and facts" by Kogan and Trahtman
}

D Beysens, I Milimouk, Vadim Nikolayev, S Berkowicz, M Muselli, B Heusinkveld, A. F. G. Jacobs

\section{To cite this version:}

D Beysens, I Milimouk, Vadim Nikolayev, S Berkowicz, M Muselli, et al.. Comment on "The moisture from the air as water resource in arid region: Hopes, doubt and facts" by Kogan and Trahtman. Journal of Arid Environments, 2006, 10.1016/j.jaridenv.2006.01.011 . hal-01262864

\section{HAL Id: hal-01262864 \\ https://hal.science/hal-01262864}

Submitted on 28 Jan 2016

HAL is a multi-disciplinary open access archive for the deposit and dissemination of scientific research documents, whether they are published or not. The documents may come from teaching and research institutions in France or abroad, or from public or private research centers.
L'archive ouverte pluridisciplinaire HAL, est destinée au dépôt et à la diffusion de documents scientifiques de niveau recherche, publiés ou non, émanant des établissements d'enseignement et de recherche français ou étrangers, des laboratoires publics ou privés.

\section{(1) (1) $\$$}

Distributed under a Creative Commons Attribution - NonCommercial - NoDerivatives 44.0 
Comment on "The moisture from the air as water resource in arid region: hopes, doubt and facts" by Kogan \& Trahtman

D. Beysens ${ }^{a, b, *}$, I. Milimouk ${ }^{b, c}$, V. Nikolayev ${ }^{a, b}$, S. Berkowicz ${ }^{\text {b,d }}$, M. Muselli ${ }^{\text {b,e }}$, B. Heusinkveld ${ }^{\text {f }}$ \& A.F.G. Jacobs ${ }^{\text {b, }}$

${ }^{a}$ CEA-ESEME, Service des Basses Températures, CEA-Grenoble, Grenoble, France and ESPCI-PMMH, 10 rue Vauquelin, 75231 PARIS Cedex 05, France

${ }^{\mathrm{b}}$ International Organization for Dew Utilization (OPUR), 60 rue Emériau, 75015 Paris, France

${ }^{c}$ CNRS-ESEME, ICMCB, 87, Av. Dr. A. Schweitzer, 33608 Pessac, France

${ }^{\mathrm{d}}$ Minerva Arid Ecosystems Research Centre, Institute of Earth Sciences, Givat Ram

Campus, Hebrew University of Jerusalem, Jerusalem 91904, Israel

${ }^{\text {e }}$ Faculté des Sciences et Techniques, Université de Corse, UMR CNRS 6134, Route des Sanguinaires, 20000 Ajaccio, France

${ }^{\mathrm{f}}$ Meteorology and Air Quality Group, Wageningen University, Duivendaal 2, 6701 AP Wageningen, The Netherlands

*Corresponding author. E-mail: dbeysens@cea.fr

submitted to J. of Arid Environments

Short title: Comment on Kogan \& Trahtman - Moisture from air

Key words : Aerial wells, dew, dew condensers, Feodosia

May 18, 2005 


\begin{abstract}
Kogan \& Trahtman (2003) analyzed the functioning of a passive dew condenser built by F.I. Zibold in 1912 in Feodosia, and proposed a model to explain how thousands of litres of condensed water might be generated per day based on Zibold's design. In a previous publication, some of the present co-authors explained why it was not possible to obtain high water yields with Zibold-style dew condensers and that Zibold was apparently unaware that the stone heaps in Feodosia were in fact ancient Scythian and Greek tombs. Kogan \& Trahtman (2003) take issue with our findings, thus the reason for this comment.
\end{abstract}

\title{
Introduction
}

We comment on the work of Kogan and Trahtman (2003) (hereafter referred to as K \& T) in which they propose a pyramid-like structure that, they believe, can work as a passive dew condenser to generate thousands of litres of water per day. Their theory is based on a dew condenser built by a Russian forester, F.I. Zibold (1850-1920), in 1912 in Feodosia (lat. $45^{0}$ 01'; Long. $35^{0} 22^{\prime}$, Ukraine). Zibold had noticed numerous ancient stone heaps in the region and hypothesized that the heaps had once functioned as dew condensers to supply the inhabitants with water. For the benefit of the reader, we preface our comments with some background information below.

Dew has fascinated Man for over 2000 years, and references to this phenomenon can be found in ancient and modern poetry and literature, folklore, and the Bible. Scientific interest in dew has had an equally long history (Middleton, 1965). The publication by Monteith (1957) can be considered a marker in the shift in dew research, from observation and proxy dew measurement attempts, towards understanding energy and heat balance mechanisms of dew formation and dew evaporation. Monteith (1963) also saw the necessity of highlighting some dew fallacies to the scientific community. 
The possibility for collecting dew or fog water arose primarily in response to frequent visual observations of surfaces moistened by these phenomena. Such collection is particularly attractive for remote areas, islands, and regions where rainfall is low or confined to a given season, and where groundwater, springs or streams may not be available or accessible.

In the last 20 years, fog water collection has garnered considerable attention as a potential alternative or supplemental source of freshwater for domestic or agricultural consumption (Schemenauer and Cereceda, 1992). The system relies on a mesh intercepting fog droplets that, by gravity, trickle down to a trough below and which then run into a storage tank. In an arid region of Chile, Schemenauer and Cereceda (1994) carried out a large-scale fog water project that produced, on average, $11,000 \mathrm{~L} \mathrm{~d}^{-1}$ with a maximum of about $100,000 \mathrm{~L}$ $\mathrm{d}^{-1}$. In their study, the mesh collecting area was originally $2400 \mathrm{~m}^{2}$ and was subsequently increased to $3600 \mathrm{~m}^{2}$. The project succeeded in sustaining a nearby village of 330 people with their daily water requirements. Of course, this method is limited to areas where topographic and meteorological conditions are favourable to frequent and persistent fogs.

In contrast to fog, dew results from the condensation of water vapour on a given surface. The surface properties will determine when and if the dew-point is reached. Not surprisingly, there is no standard instrument for measuring dew (Berkowicz et al., 2001). The amount of dew that may form naturally on a given surface, however, is theoretically limited to under $1 \mathrm{~mm}$, i.e. $1 \mathrm{~L} \mathrm{~m}^{2}$ (Monteith, 1957; Garratt \& Segal, 1988). Dew, on the other hand, occurs in most regions of the globe. Over the last decade, passive dew collectors have been built using materials that can enhance radiative cooling and thus improve dew collection output (Nilsson et al., 1994; Nilsson, 1996; Muselli et al., 2002; Beysens et al., 2003).

Problems arise when the principles of dew formation are not well understood, especially when coupled with folklore, which may generate inaccurate expectations for passive dew collection. A recent article by Pearce (2005), a science and environment writer 
for the journal New Scientist, raised the question of dew as a water source and included a short review of the $\mathrm{K} \& \mathrm{~T}$ publication. Pearce began his article with the so-called "dewponds" found in the English countryside that were considered to generate their own water through special construction and site selection. English folklore claimed that these ponds, about $1 \mathrm{~m}$ deep and up to about $8 \mathrm{~m}$ in diameter, were partly filled by rain but replenished primarily by dew. Pearce then provided an explanation of how the dewponds apparently worked. Richards (2004, p. 85), in reviewing dew in rural and urban environments, wrote:

"However not all dew collection stories are grounded in truth. "Dewponds", i.e., shallow ponds in rural England that provide water for stock, are unquestionably rain filled, and may even have been named for a nineteenth-century pond-maker, Mr. Dew...."

Pearce, however, is under the impression that dewponds are in fact filled by dew.

One must be careful to distinguish folklore from fact. For example, in 1869 , in the northern Negev desert, the philologist E.H. Palmer first recorded the presence of thousands of low heaps of stones. As the local Bedouin guides referred to them as teleilat el anab, i.e. "grape mounds", Palmer understood that grapes were able to grow on the stones as a result of dew condensation. However Evenari et al. (1982), who investigated the mounds, observed that the stones never dripped from dew. Following several years of research, the Evenari team determined that the mounds were devised by the ancient Nabateans to facilitate runoff by removing surface obstacles such as stones. In this way copious amounts of rainwater could be funneled into cisterns excavated at the lower slopes, or led directly into the agricultural fields below. Accordingly, the residents were able to exist in a desert region having about $100 \mathrm{~mm}$ annual rainfall mainly distributed between November to February.

In a study on the Zibold collector, previously published by some of the co-authors of the present article (see Nikolayev et al., 1996), we show that the greater the heat capacity of a 
condenser, the poorer the potential water yield, hence the failure of Zibold-style pyramid condensers. It is this conclusion that is criticized by $\mathrm{K} \& \mathrm{~T}$ (p. 235) as being "too hasty and unfounded".

Below we explain why the proposed passive Zibold-style pyramid dew condenser by $\mathrm{K} \& \mathrm{~T}$ cannot generate the amounts of water they claim is possible. In addition, comments they make supporting the idea that the ancient stone heaps of Feodosia were apparently dew condensers are in error, and thus could not have supplied the daily water needs of $19^{\text {th }}$ century Feodosia (population then of 11,000 according to $\mathrm{K} \& \mathrm{~T}$ ): This includes:

"The purpose of our work is estimation of the ability of the Crimea stone heaps
to collect dew..." (p. 232),

"Nevertheless, one can find today in Crimean forests some another kind of water consenser also called "fountains" by Crimean inhabitants. The size of the installations is like the size of a little house. The water leaks from the pipe going out from the lower part of the construction." (p. 232),

"We conclude that the water supply of Feodosia for many years was on the level of $60,000 \mathrm{~L} \mathrm{day}^{-1}$ (or greater), and we do not know today of another source of drinking water except the stone heaps on the mountains near this town." (p. 233).

We believe their theoretical model can lead to false expectations on the quantities of water that can be attained from passive dew collection and thus it is our obligation to bring this to the attention of the scientific community. 


\section{Discussion}

The reader is directed to both $\mathrm{K} \& \mathrm{~T}$ and Nikolayev et al. (1996) for the required background reading. In brief, there is a myth that the ancient Greeks, who founded the present-day Feodosia about 600 BCE, constructed pyramid-shaped dew condensers composed of stone to supply their daily water requirements. Recent records of annual rainfall for Feodosia show an average of $366 \mathrm{~mm} / \mathrm{year}$. Let us assume for the sake of argument that the climate at $600 \mathrm{BCE}$ was similar or drier. The remains of these structures intrigued a Russian forester working in the region, F.I. Zibold, who attributed these remains to ancient dew condensers. By 1912, Zibold constructed a working dew condenser based on his conception of what the ancient Greeks may have designed and intended.

Jumikis (1965, p. 84) provides a good summary :

"The slopes of the chain of mountains that surrounded the Crimean peneninsula in a semicircle were transformed into wooded terraces comprising an area of 10,000 hectares. In the course of the leveling operations, F.I. Siebold, the engineer, discovered a network of tile pipe, 5 to $7 \mathrm{~cm}$ in diameter, and channels filled with crushed rock. By 1883 , some 8400 of these tile pipes (stone tubes) had been uncovered. The first pipes found led to 114 dried-up, abandoned cisterns in the town, and those found later to the crests of the mountain chain surrounding Theodosia, 300 to $320 \mathrm{~m}$ above sea level. Although Siebold observed that the pipes and channels carried some water from the mountains, he could find no trace of springs. Continuing his search, he found that the pipes and channels ended in enormous pyramids of crushed calcareous rock of odd shapes and 5 to $10 \mathrm{~cm}$ in size. Thirteen of these pyramids were 
found spaced over a distance of about $3 \mathrm{~km}$. Each measured approximately 30 $\mathrm{m}$ in length, $25 \mathrm{~m}$ in width and $10 \mathrm{~m}$ in height......

Siebold....thought the wells may have functioned as follows: upon entering the cool interior (aerial well) through the voids in the pile of crushed rock, the atmospheric vapour would chill and transform into water, which then flowed through the tiles to fill Theodosia's water cisterns. He also calculated, on the basis of an 8-hour day and the size of pipe, that each of the 13 condensers would produce 55,400 liters of water per day. Thus the whole installation of 13 condensers and 114 cisterns (including rainwater) could have supplied a town with about 721,200 liters of potable water a day.

According to Hitier (12), Siebold at first intended to reestablish the operation of these enormous condensers. Unfortunately, the heavy dust and the vegetation of many centuries had clogged and obstructed the openings and the voids of the crushed rock fragments in the pile...."

Co-authors IM and DB visited Feodosia in 1993 and 1994 and tracked down all available documents written by Zibold and others, either as private notes or presented at conferences, involving the Zibold dew condensers (translated into French by IM and DB and compiled in Anonymous, 1915, 1935). The search included the Feodosia Museum and archives. As indicated in Nikolayev et al. (1996), the Zibold condenser yield data were never found recorded in any document. It is extraordinary that not a single available publication, note, conference or commentary on the Zibold condenser ever contained any of Zibold's data. Furthermore, none of these documents even cites any work by Zibold that may have contained his data. There is only a single passing reference to Zibold's condenser output, made by N.N. Joukov in a report published in 1931 (see Anonymous, 1935, p. 73). Joukov cited a worker in 
Zibold's forestry department, Nikitas, who indicated that the Zibold condenser gave a maximum yield in 1912 of 360 litres of water per day (value converted from the volume unit used at the time). The report was prepared by Joukov in Feodosia and dated August 1930, i.e. a passage of 20 years for the yield to be published.

K \& T (p. 232) write that:

“The daily output of the 'fountains' was studied twice: in October 1874 (eight 'fountains', 66,000 1), and in May 1882 (five 'fountains', 57,000 1). Zibold found in 1905 ten stone heaps considered as water condensers and printed the volumes of five of them: 2900, 1970, 1450, 1250, $1250 \mathrm{~m}^{3}$. So we can consider the average stone heap volume of $1664 \mathrm{~m}^{3}$. If we suppose that the number of active condensers was not less than eight in 1874 or five in 1882 and not greater than 13 in 1874 or 10 in 1882 , then we can derive that 5100 11,4001 was the production limits for a single stone heap per day. "

The $\mathrm{K} \& \mathrm{~T}$ source of information (Zibold, 1905) is no more than a two-page report concerning a communication that Zibold delivered in 1905 at a session of the Meteorological Commission of the Russian Imperial Geographic Society. Apart from summarizing the Zibold theory about dew condensation in the stone heaps, the report is very skeptical about the possibility to feed - with dew water - a city with thousands of inhabitants. It however recommended the study of dew condensation as Zibold envisaged. We thus assume that $\mathrm{K} \&$ T relied upon Anonymous (1935), in which N.N. Joukov published, in 1931, data on water obtained from dew condenser "fountains" that had apparently been carried out on October 30,1874, and on May 29,1882. Furthermore, the "fountains" may have also referred to water obtained from drainage trenches and gullies that were dammed to trap rain water (explained in 
further details below). Given the 50-year difference in time, we must consider both observations as anecdotal.

The Feodosia stone heaps referred to by K \& T have been excavated for over 200 years. Co-authors DB, IM and VN participated in two excavations in 1994 (Beysens et al., 1996). It is well known from archeologists specializing in the Black Sea region, for example Dr. E. Katiushin (Museum for the Study of Feodosia, Feodosia, Ukraine) and Prof. J.-P. Morel (Centre National de la Recherche Scientifique, Univ. de Provence, France), who both participated in excavations, that these stone heaps are Scythian and Greek tombs (personal communications and Katiushin, 1979). Based on the results of the archaeological excavations, Katiushin (1979) supported the opinion that the chain of mounds described by Zibold was part of the necropolis of ancient Theodosia. Indeed, since the 1850's, more than 80 mounds in the surroundings of Feodosia have been excavated (including our own excavations, Beysens et al., 1996). The mounds, without exception, proved to be the tombs of either the ancient Greeks or Scythians. The mounds can be dated to $4^{\text {th }}-3$ rd Cent. B.C.E.

These excavations revealed neither tubes nor water channels under the mounds that could collect water. In support of their theories, however, $K \&$ T claim (p. 232) that "there was no trace of springs. The pipes and channels ended in enormous pyramids of crushed calcareous rock of odd shapes and 5-10 cm in size (Fig. 1)". They go on to state (p. 233) that “...we do not know today of another source of drinking water except the stone heaps on the mountains near this town". This claim is incorrect. There are numerous springs in the neighborhood of Feodosia as well as an old sophisticated network of ducts to channel underground water. In some cases, such spring water collection gave rise to artificial or manmade reservoirs (see Beysens et al., 1996, and photos therein). However, the conduct network is so dense that pipes are found everywhere, including near the stone heaps. 
Even if we assume that 66,0001 could be produced every day - assuming that the appropriate meteorological conditions for dew condensation were always optimal - during the 1870 's and 1880 's, that would work out to a very meager $6 \mathrm{~L} \mathrm{~d}^{-1}$ per person (population 11,000) available for drinking, household needs, farming and grazing animals.

So what were the water sources in Feososia? A recent publication by Kovalchuk (2004, p. 51) interestingly continues to cite that the natural or man-made stone heaps in the area served as dew condensers, but nevertheless explains that there were other natural sources :

"In addition, another tool for water accumulation was used based on use of drainage trenches dug on the mountainsides in the chess [sic] order and filled with crushed rock. Water from the trenches flew into wells, and from there into stone pools called fountains. Distribution fountains in the town were stone cisterns closed by plates, as well as open pools the inhabitants took water from. From some pools water flew through ceramic pipes into wells. Rain water was also consumed, which was collected as a result of damming at gullies' mouths."

Kovalchuk (2004, p.52) concludes:

“Also, springs played important role in water supply of the Great Feodosia area. The most powerful of them is located in the region of old Crimea, at the sides of Aharmysh Mounting. It is Subashi spring, which produces about 751 of water per second. In the early days, Subashi spring source provided the villages of Subashi and Sheikh-Mamat with water, as well as was used for irrigation of up to 250 ha of land in this area. In the XV century the Genoa people, and later 
Turks used water of Subashi and nearby Krynychka spring for supplying not only Feodosia, but also all Kerch Peninsula. In 1888 the Town received water from the Subashi source, which was granted to the Town by I. K. Aivazovski (50,000 buckets per day). Besides water pipeline from the Subashi source, water took also from Koshka-Chokrak sources...."

Alekseev \& Berezkin (1998) write :

"During a heyday of the city [Feodosia] in the Middle Ages there were up to 100 fountains, which provided with water [for] 80 thousand city dwellers. They got water from the wells of Feodosian mountains slopes. Some wells were situated just near watersheds. The water was bridged to them by gravity through potter pipes.... These wells were supplied by water from detritus heaps 2-5 $\mathrm{m}$ high and 1000-2000 $\mathrm{m}^{3}$ or more in volume (Zibold, 1905). They were used for rain water collecting. In drought summer days they condensed moisture from the atmosphere."

If, as Jumikis (1965, p. 84) notes, that "the heavy dust and the vegetation of many centuries had clogged and obstructed the openings and the voids of the crushed rock fragments in the pile....", thus leading Zibold to build a new one, then obviously there had to other water sources.

Figure 1 of $\mathrm{K} \& \mathrm{~T}$ displays a sketch of an apparent tomb and not a dew collector. In contrast to their sketch, there is in general no drain in the stone heaps and they rather resemble a cone with a funnel at the top - exactly what Zibold mimicked (Figs. 1a and 1b). 
Figs $1 \mathrm{a}$ and $1 \mathrm{~b}$

$\mathrm{K} \& \mathrm{~T}$ claim that the funnel at the top of this "condenser" was specifically created by its designers and served to focus solar radiation. According to archeologists (E. Katiushin and J.-P. Morel, personal communications), these Scythian and Greek tombs were designed to be protected by rocks to hinder plundering. Attempts by plunders resulted in these funnels.

The reader is referred to $\mathrm{K} \& \mathrm{~T}$ for their mathematical model of how the Zibold condenser produced dew (pp 235-237) and their mathematical explanation of how "air draught" ventilation within a stone heap can produce condensation during the day. In brief, their models and explanations do not conform to any physical background that we are aware of. Their parameters are confusing or undefined. They do not define what a "grade" is, though they frequently refer to it (p. 236).

We would like to stress the following point. To obtain condensation, the condenser temperature of the stones must be lower than the dew point temperature. When there is no fog, the dew point temperature is always lower than the air temperature. Meteorological data shows that the dew point temperature (an indicator of the water content of the air) does not change appreciably when the weather is stable (Ephrath et al., 1996). Thus wind, which ultimately imposes air temperature to the condenser, cannot cool the condenser to ensure its functioning. Another cooling phenomenon - radiative cooling - must operate. It is therefore at night-time, when the condenser cools by radiation, that liquid water can be extracted from air. It is very rare that the dew point temperature would increase significantly so as to exceed the stone temperature inside the stone heap. Occasionally, when it happens, dew can be abundant during a short period of time. This is why subsequent attempts by L. Chaptal and A. Knapen 
to build massive dew condensers (Chaptal, 1932; Knapen, 1929) only rarely experienced significant yields.

$\mathrm{K} \& \mathrm{~T}$ go on to assert (p. 235) that a 100 times thicker working layer of stones would increase the condenser water yield 100 times. However, the opposite is true. Figure 6 of Nikolayev et al. (1996) shows that such a condenser would be much worse. In addition, the working layer cannot be as thick. The temperature deep in the stone heap is essentially equal to the average day temperature, which is higher than the dew point temperature.

Although radiative cooling can provide some amount of liquid water, the water yield cannot exceed the radiative cooling energy needed to transform water vapor into liquid water (the latent heat) (see also Muselli et al., 2002). Straightforward calculations based on -100 $\mathrm{W} / \mathrm{m}^{2}$ (a very "high" value) gives theoretical maximum dew yields of about $0.5 \mathrm{~L} \mathrm{~m}^{-2}$ of condenser surface per night.

It is interesting to discuss how large the volume $V_{a}$ of air has to be to yield a given condensed mass $m$ and how much time $\Delta t$ will be necessary for air to remove the corresponding latent heat. During the (rare) events where the pebble temperature is lower than the dew temperature, condensation takes place and the latent heat $\left(L=2500 \mathrm{Jg}^{-1}\right)$ is released to the pebbles. Temperature of the latter increases till condensation stops. According to the $\mathrm{K} \&$ $\mathrm{T}$ theory, further cooling by air draught (volume $V_{a}$ ) will be necessary to initiate another condensation process. We consider the temperature difference between pebbles and air to be $10 \mathrm{~K}$. With $C_{a}=1 \mathrm{Jg}-1$ the air heat capacity and $\rho_{a}=1 \mathrm{gL}^{-1}$ the air volumic mass, one obtains

$$
V_{a}=\frac{m L}{\rho_{a} C \Delta T} .
$$

Using the $\mathrm{K} \& \mathrm{~T}$ numbers for $\imath(10 \mathrm{~K})$ and $m(13000 \mathrm{~kg})$, corresponding to a condensing structure of $V_{s}=1664 \mathrm{~m}^{3}$, one readily finds $V_{a}=3.2510^{6} \mathrm{~m}^{3}$. What is the time $\Delta t$ necessary to 
convect such a volume of air? We need to determine the air velocity $U$ due to natural convection between the rocks, which is extremely difficult to estimate. By comparison with free convection in the open air where air velocity is of order on $0.1 \mathrm{~ms}-1$, one can reasonably state that $U<0.01 \mathrm{~ms}^{-1}$. Thus

$$
\Delta t>\frac{m L}{U S \rho_{a} C \Delta T} .
$$

Here $S$ is the cross-section of the convective flow. It can be estimated as $S \approx V_{s}^{2 / 3}=140 \mathrm{~m}^{3}$. One then obtains the very large and unphysical time $\Delta t=2.310^{6} \mathrm{~s}=27$ days. Changing some values like $U$ or $S$ by a factor of 2 will not change its improbability.

In addition, Alexeyev \& Berezkin (1998a) wrote that all the tombs were situated at heights well above sea-level and in open areas, thus exposed to mean wind speeds that have been measured at 6.7-7.5 $\mathrm{m} \mathrm{s}^{-1}$. We would welcome seeing the air volume and wind speed calculations by $\mathrm{K} \& \mathrm{~T}$ for producing $1000,5,000$ and $10,000 \mathrm{~L} \mathrm{~d}^{-1}$ and an estimate of what would be their theoretical minimum size of a collector to produce $1 \mathrm{~L}$ of condensation. Although wind is needed to bring humid air to the condensing surface, the windspeed must lie within a certain range. Still air will inhibit moisture input from more humid layers above, while strong winds will cancel out radiative cooling effects and induce warming. Monteith (1957) found that the minimum wind speed for a short grass surface is $0.5 \mathrm{~m} \mathrm{~s}^{-1}$ at $2 \mathrm{~m}$, however a light wind under $1 \mathrm{~m} \mathrm{~s}^{-1}$ appears optimal (Beysens, 2003). Muselli et al. (2002, p. 304, Fig. 5), working on a hillslope in the coastal city of Ajaccio on the island of Corsica (France), found that $3 \mathrm{~m} \mathrm{~s}^{-1}$ tended to be the upper limit for dew collection based on one year of observations using a special thin dew condensing foil. On only 15 occasions were there dew yields with windspeeds between 3-4.5 $\mathrm{m} \mathrm{s}^{-1}$. 
$\mathrm{K} \& \mathrm{~T}$ also describe the benefit of a concave depression at the top of a pyramid-shaped condenser in that it would generate an updraught within the structure to encourage condensation. $\mathrm{K} \& \mathrm{~T}$ do not indicate what would be the speed of such an updraught or how it would vary by season. If the incoming wind is horizontal or at an angle to the structure, then in the daytime - when $\mathrm{K} \& \mathrm{~T}$ claim that the condenser could still function - wouldn't the required high windspeeds overwhelm such an updraught ?

Chaptal built two large dew condensers, based on the Zibold condenser, with both experiments ending in failure. Jumikis $(1965$, p. 90) noted that :

"Disappointed by its improper functioning, Chaptal, upon his retirement in 1946, ...put the receptor [dew condenser] out of order..... Supposedly Chaptal did this because he did not want to leave an improper installation to mislead those who might later want to resume and continue studies on aerial wells."

K \& T state (p. 234) that "real condensed [dew] water contains minerals", but make this assertion by mistakenly referring to the quality of fog water, making reference to Schemenauer \& Cereceda (1992). On the contrary, dew water, which is essentially distilledlike water, contains a very small amount of minerals (Muselli et al., 2002). What does influence dew chemistry, however, is the nature of the dew condensation surface. Air pollution (vehicle exhaust, home heating, industry) and dust deposits on the condensation surface will affect the chemistry of the condensed dew and extent of suspended solids found on the condensation surface. These are important properties in determining whether collected dew water is potable. 


\section{Conclusions}

The passive dew collector design offered by $\mathrm{K} \& \mathrm{~T}$ is in error and could not generate - as they claim - thousands of litres per day. The ancient stone heaps of Feodosia were never dew condensers but just the remains of Greek or Scythes tombs. Although Zibold made a courageous attempt to build a passive dew condenser modelled on the stone heaps, the source of his inspiration was misleading.

As a matter of fact, there are no documented reports of dew condensers working based on that principle. $\mathrm{K} \& \mathrm{~T}$ cite Alexeyev \& Berezkin (1998a) as a source of information for both the Zibold collector and development of their model. An extract of this paper, in English, was published in the same year (Alekseev \& Berezkin, 1998b) in which they state :

"At the first stage of our project, we are going to make a pilot module...imitating one condensor of [the] Feodosian type....It is supposed that the module will give approximately $10-25 \mathrm{~m}^{3}$ of fresh water per day."

We have not come across any published results. We did find one reported attempt to build a Zibold-type dew condenser. Bowen (2004), writing for an American newspaper, interviewed a man claiming to have done so:

He said the design came from the University of Moscow, based on the ancient Feodosia model. "I built a structure based on their instructions to see how it works in this part of Texas. "It didn't work very well". He modified the Russian model with some success, but eventually abandoned it. "I thought I 
could build it and just watch the water drip off. But it didn't just drip off of it the way I hoped it would."

Research concerning passive or mechanical dew collection are welcome in a world where drinking water is limited. But simulation should go hand-in-hand with experimentation. High quality dew water can be usefully collected with open air radiative collectors, but with a water yield that will normally not exceed $0.5 \mathrm{~L} \mathrm{~m}^{-2}$. In contrast to massive dew condensers, radiation-cooled light condensers exhibit non negligible yields and are being used in Corsica island (France), Bisevo island (Croatia), Jerusalem (Israel) and Kothara (India), the latter being funded by the World Bank.

\section{References}

Alexeyev, V.V. \& Berezkin, M. J. (1998a). Fresh water from air, Priroda, 6: 90-96. (in Russian).

Alekseev, V.V. \& M.J. Berezkin, M.J. (1998b). Fresh water from atmospheric vapour for arid regions. Renewable Energy Bulletin, 3:36-38. Available on http://www.intersolar.ru/bulletin/eng/3/al_berezkin.shtml

Alexeyev, V.V. \& Rustamov, N.A. (1998). Water from air, Ecologiya i zhizn', 1: 44-47. (in Russian).

Anonymous (1915). Proceedings of the inspection of the condenser, which was built in the Feodosian forest, 19.06.1915. (In Russian, manuscript kept in the Feodosian museum). 
French translation Milimouk, I. \& Beysens, D., Rapport CEA-Saclay, 1995, DIST No. 95002495 .

Anonymous (1935). Stenograph of the Proceedings of the 1st Conf. on the condensation of water vapor (Aerial well). Moscow-Leningrad (In Russian, manuscript kept in the Feodosian museum). French translation Milimouk, I. \& Beysens, D., Rapport CEASaclay, 1995, DIST No. 95002495.

Berkowicz, S.M., Heusinkveld, B.G. \& Jacobs, A.F.G. (2001). Dew in an arid ecosystem: Ecological aspects and problems in dew measurement. Proc. 2nd Intl. Conf. Fog and Fog Collection, 15-20 July 2001, St. John's, Newfoundland, Canada. Pp. 301-304.

Beysens, D., Gioda, A., Katioushine, E., Milimouk, I., Morel, J-P. \& Nikolayev, V. (1996). Les puits de rosée, un rêve remis à flot. La Recherche, 287: 30-33; id, "Los pozos de rocio, un sueno reflotado" Mundo Cientifico, 170: 620-623.

Beysens, D., Milimouk, I., Nikolayev,V., Muselli, M. \& Marcillat, J. (2003). Using radiative cooling to condense atmospheric vapor: a study to improve water yield. $J$. Hydrology, 276: 1-11.

Bowen, G. (2004). From thin air : Cheapside man hopes to capture vapor for new public water supply. Victoria Advocate (Texas, USA), October 3, 2004. http://www.thevictoriaadvocate.com/lifestyle/features/story/2242807p-2599362c.html

Chaptal, L. (1932). La captation de la vapeur d'eau atmosphérique. La Nature, 60 (2893): 
449-454.

Ephrath, J.E., Goudriaan, J. \& Marani, A. (1996). Modelling dirunal patterns of air temperature, radiation, wind speed and relative humidity by equations from daily characteristics. Agricultural Systems, 51: 377-393.

Evenari, M., Shanan, L. \& Tadmor, N. (1982). Negev : The Challenge of a Desert. $\left(2^{\text {nd }}\right.$ Edn). Cambridge, Mass : Harvard Univ. Press. 437 pp.

Garratt, J.R. \& Segal, M. (1988). On the contribution of atmospheric moisture to dew formation. Boundary-Layer Meteorol., 45:209-236.

Joukov, N.N., 1931. About the ancient hydrotechnical constructions in the surroundings of Feodosia. Collection of articles on economy, mode of life and history of the Feodosian region. No. 1, Feodosia (in Russian, manuscript kept in the Feodosian museum). Translation into French by Milimouk, I. \& Beysens,D., Rapport CEA-Saclay, 1995, DIST No. 95002495 .

Jumikis, A.R. (1965). Aerial wells : secondary sources of water. Soil Science, 100 (2) :8395.

Katiushin, E.A., 1979. Excavations in the surroundings of Feodosia. Arheologitcheskie otkrytija 1978 goda. Moscow: Nauka, pp. 334-339 (in Russian).

Knapen, M.A. (1929). Dispositif intérieur du puits aérien Knapen. In : Extrait des 
Mémoires de aa Société des Ingénieurs Civils de France (Bulletin de Janvier-Février 1929) : Imprimerie Chaix, Paris.

Kogan, B. \& Trahtman, A. (2003). The moisture from the air as water resource in arid region: hopes, doubts and facts. J. Arid Environ., 53: 231-240.

Kovalchuk, A. (2004). Using local water resources for solving drinking water problems in the Town of Feodosia. In: Implementation of the Technical Solutions of Drinking Water Problems, Carried Out Ukrainian Environmental NGO MAMA-86 in the Framework of the Pilot Projects Program within the Campaign "Drinking Water in Ukraine" 2001-2003. 22 Mykhailivska Street, Kyiv-1, 01001, Ukraine. Website: http://www.mama-86.org.ua

Middletown, W.E.K. (1965). A History of the Theories of Rain and Other Forms of Precipitation. Chapter 9, Theories of dew and hoar frost. Franklin Watts, New York. Pp. 177-193.

Monteith, J.L. (1957). Dew. Q. J. Royal Meteorol. Soc. 83: 322-341.

Monteith, J.L. (1963). Dew facts and fallacies. In: A.J. Rutter and F.H. Whitehead (eds.), The Water Relations of Plants. Blackwell Scientific Publications, Oxford, pp. 37-56.

Muselli, M., Beysens, D., Marcillat, J., Milimouk, I., Nilsson, T. \& Louche, A. (2002). Dew water collector for potable water in Ajaccio (Corsica Island, France). Atmospheric Research, 64: 297-312. 
Nilsson, T. (1996). Initial experiments on dew collection in Sweden and Tanzania Solar Energy Materials Solar Cells, 40: 23-32.

Nilsson,T., Vargas,W.E., Niklasson,G.A. \& Grangvist, C.G. (1994). Condensation of water by radiative cooling. Solar Energy, 5:310-317.

Nikolayev, V., Beysens, D., Gioda, A., Milimouk, I., Katiushin, E. \& Morel, J.-P. (1996). Water recovery from dew. J. Hydrology, 182: 19-35.

Pearce, F. (2005). Pyramids of dew. New Scientist, 16 April 2495: 52-53.

Richards, K. (2004). Observation and simulation of dew in rural and urban environments. Prog. Physical Geog., 28:76-94

Schemenauer, R. \& Cereceda, P. (1992). The quality of fog water collected for domestic and agricultural use in Chile. J. Appl. Meteorology, 31: 275-290.

Schemenauer, R. \& Cereceda, P. (1994). Fog collection's role in water planning for developing countries. Natural Resources Forum, 18:91-100. 


\section{Figures captions}

Fig. 1

(a) Photo of the southern side of the Zibold condenser in 1912 (Contained in V. Tougarinov, Condensation of atmospheric water vapour. Proceedings of the $1^{\text {st }}$ Conference on Water Condensation (1931), UTSEGMS, Moscow, 1935 (in Russian);

French translation: Report CEA-Saclay, 1995, DIST Ref. 95002495.

(b) model of the Zibold condenser in 1912 (photo D. Vinçon).
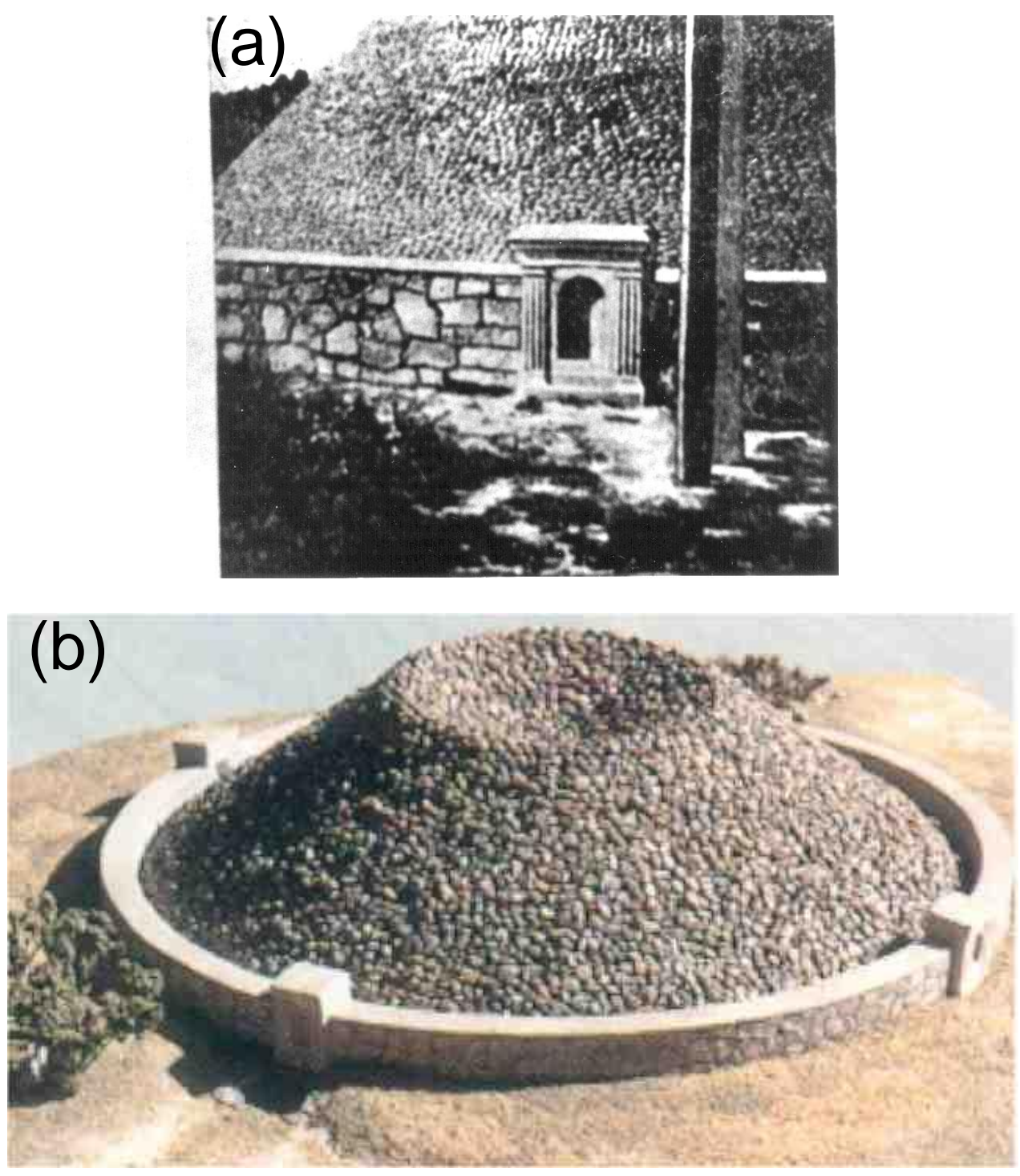